\title{
Insect Flower Visitors and their Role in Mangrove Pollination: A Study from East Coast of India
}

\author{
M. Panda ${ }^{1,3 *}$, N. Lele ${ }^{2}$, R.N. Samal ${ }^{3}$, D. Dalai ${ }^{4}$, S.P. Parida ${ }^{5}$ and T.V.R. Murthy ${ }^{2}$ \\ ${ }^{1}$ Department of Botany, Banki (Autonomous) College, Odisha, India \\ ${ }^{2}$ Space Application Center (SAC-ISRO), Ahmadabad, India \\ ${ }^{3}$ Chilika Development Authority, Department. of Forest and Environment, Odisha, India \\ ${ }^{4}$ Research Scholar, National Rice Research Institute, Odisha, India \\ ${ }^{5}$ Centurian University of Technology and Management, Odisha, India
}

Date Received: 23-02-2019

Date Accepted: 16-12-2019

\begin{abstract}
Insects play a critical role in bringing successful pollination in angiosperms. Mangrove pollination is a poorly studied aspect from scientific community. This particular work investigated the insect visitors and other prospective of mangrove flowers. Twenty two species (i.e., 17 true and 5 mangrove associates) from Bhitarkanika Wildlife Sanctuary and Devi estuary of Odisha state (East coast of India) were selected; plants were pre-marked and visiting insects were recorded starting from 07.00 am to $13.00 \mathrm{pm}$ during the flowering period of each species. Fifty three species of insects which belongs to seven orders, twenty five families and forty four genera were recorded. The highest, i.e., $14 s p$. of insects had been recorded from Aegiceras corniculatum which is a small tree and riverine mangrove. Among insects, bees were found as the most common flower visitors (in $82 \%$ mangroves) and particularly "honey bee", i.e., Apis dorsata visited to sixteen mangrove species (i.e., 73\% mangroves). Bees, particularly Honeybee ( $A$. dorsata), sweet bee (Lasioglossum sp.) and carpenter bee (Xylocopa pubescens) were actively engaged in pollen dispersal. Resident time and visitation rate supported that bees with highest visitation rate and low resident time were powerful candidates in bringing mangrove pollination. Wasps, beetles and butterflies act more to be foraging species. Facilitation of bee management and particularly supporting apiculture will help to increase pollination successes of rare and threatened mangroves at regional and global level.
\end{abstract}

Keywords: Mangrove, flower, pollination, bees, forest conservation

\section{Introduction}

Mangrove ecosystems are well known in terms of productivity, role of coastal protection, a habitat for diverse flora and fauna and most importantly as a large carbon pool both in living tissues and in the form of sediments. Mangal loss is over alarming and thus had been legalised in many countries. Long term conservation only possible through maintaining a stable population structure and flora diversity in the ecosystem. This depends on successive reproduction and subsequent regeneration of mangrove species. Pollinators are one such group whose effective management can maximise reproductive success of rare and endemic mangroves. Pollinators depend less on the plants than the plants on them (Tomlinson, 2016). Pollination benefits society by increasing food security, improving livelihoods and act as a key driver in the maintenance of biodiversity and ecosystem function (Pratap, 2011).

Generally, pollination is done almost completely by canopy dwellers such as bats, birds, moths, butterflies, bees and other insects (Alongi, 2009). Identification of effective pollinator in forest with large

\footnotetext{
*Correspondence: muktipadapanda@gmail.com ISSN 2235-9370 Print/ISSN 2235-9362 Online @ University of Sri Jayewardenepura 78
} 
canopy like mangrove is difficult. Tomlinson (2016) described pollination in terms of flower visitors that is presumed pollinators. Wild pollinators (mostly bees and flies) can be quite important for plants requiring insect pollination (Capinera, 2010). Not all bees gather nectar and produce honey but all of them gather and store up pollen grains and do cross pollination in flowering plants (Mani, 1995). The plants at most risk of loss which are dioecious and self-incompatible, and those that propagate only by seeds (Kearns and Inouye, 1997).

The floral and pollination biology of mangrove plants has been moderately studied (Raju, 1990, Raju et al., 1994, Mitra et al., 2013). Mangroves have both self-pollinating and cross-pollinating mechanisms that vary with species (Kathiresan and Bingham, 2001, Tomlinson, 2016). These pollinators are a group of animals which includes birds, bats and insects like butterflies, bees, beetles, flies and wasps etc. (Azuma et al., 2002; Ghosh et al., 2008; Ghosh and Chakrabarti, 2012; Hogarth, 2015; Tomlinson, 2016). The flowers of family Rhizophoraceae display three different pollination mechanisms i.e., Rhizophora spp.:wind pollinated, Ceriops decandra: insect pollinated and explosive pollen release in Ceriops tagal and Bruguiera spp. (Ghosh et al., 2008; Hogarth, 2015; Tomlinson, 2016). Ghosh and Chakrabarti (2012) reported bee, wasp, moth and flies are capable of pollinating in $C$. decandra. Large flowered species of Bruguiera are pollinated by birds and small flowered species of Acanthus, Aegiceras, Avicennia, Excoecaria, and Xylocarpus are probably by butterflies and various types of bees (Noske, 1993; Hogarth, 2015). Some wasps and flies are highly dependent on mangroves for nesting and are particularly important pollinators of $C$. decandra, Kandelia candel and Lumnitzera racemosa (Tomlinson, 2016). In Avicennia marina, the most common visitor was the honeybee, Apis mellifera, which is apparently attracted to the nectar-like secretion found toward the base of the corolla tube (Clarke and Myerscough, 1991).

The present study is undertaken to investigate the diversity of insect visitors and their role in pollination of twenty two mangroves (i.e., 17 true and 5 associate species) from Bhitarkanika Wildlife Sanctuary and Devi estuary (Odisha), along East Coast of India.

\section{Methodology}

\subsection{The study area}

Two mangrove ecosystems, Bhitarkanika Wildlife Sanctuary (BWS) and Devi estuary (DE) of Odisha state, along the East Coast of India were selected for present study. BWS comes under legal protection and a part of it having the mangrove forest is declared also as a National Park $\left(86^{\circ} 45^{\prime}\right.$ to $87^{\circ}$ $03^{\prime}$ E Longitude and $20^{\circ} 30^{\prime}$ to $20^{\circ} 48^{\prime} \mathrm{N}$ Latitude) in the view of better protection of mangrove species, with special reference to residing salt water crocodiles (i.e., Crocodylus porosus), Olive ridley sea turtle (i.e., Lepidochelis olivacea) and many other threatened fauna and flora residing inside and in connection to the ecosystem. It is a deltaic ecosystem established in the evolutionary process from deposition of the Brahmani and Baitarani rivers in Rajnagar coastal block of Kendrapara District. Mangrove of DE $\left(86^{\circ} 18^{\prime}\right.$ to $86^{\circ} 20^{\prime} \mathrm{E}$ and $19^{\circ} 57^{\prime}$ to $19^{\circ} 58^{\prime} \mathrm{N}$ ) is thought to be of recent formation that got established along the river bank of Devi (a distributaries of river Mahanadi). The climate of these sites is almost tropical and subtropical type. Max. rainfall in July-August (200-450 mm) and Min. in December-January (0-10 mm); Max. temperature in April-May $\left(\sim 38^{\circ} \mathrm{C}\right)$ and Min. in January $\left(\sim 15^{\circ} \mathrm{C}\right)$ and Relative humidity ranges from $60-88$ as received data from Indian Meteorological Department (IMD, Bhubaneswar) for the specified time period.

\subsection{Data collection}

Twenty two mangal species i.e., 17 true and 5 associates (Table 1; Supp. Table 1 and 2) were selected and study conducted during calendar year of 2016-2017. Five flowering twig of each species 
were pre-marked during flower bud stage. One day visual study was conducted from morning 07.00 am to $13.00 \mathrm{pm}$ during flowering time of each mangrove species. Not a single insect was captured or harmed by any means; photographs were taken using the camera, Sony Alfa SLT 58Y, DSLR (Plate 1). Insects were identified through experts' knowledge and using literatures (Mani, 1995; Chinery, 2007; Resh and Carde, 2009; Singh, 2011; Smetacek, 2017).

Table 1: Selected true mangrove and mangrove associates from two sites.

\begin{tabular}{|c|c|}
\hline True mangroves & Mangrove associates \\
\hline $\begin{array}{l}\text { *Aegiceras corniculatum (L.) Blanco, Acanthus ilicifolius L., Aegialitis rotondifolia } \\
\text { Roxb, Avicennia alba Blume, Avicennia marina (Forsk.)Veierh, Avicennia officinalis L. } \\
\text { Brumiera cylyndrica (L.) Blume, Bruguiera sexangula (Lour.) Poir, Bruguiera } \\
\text { gymnorrhiza } \text { (L) Lamk, Excoecaria agallocha L., Heritiera fomes Buch-Ham. *Kandelia } \\
\text { candel (L) Druce, Lumnitzera racemosa Wild, Rhizophora mucronata Lamk. *Sonneratia } \\
\text { apetala Buch. - Ham., Xylocarpus granatum Koenig, }\end{array}$ & $\begin{array}{l}\text { Caesalpinia crista L., Cerbera } \\
\text { odollam Gaertn, Excoecaria } \\
\text { indica (Willd.) Mull. Arg., } \\
\text { Salvadora parsica L. Tamarix } \\
\text { troupii } \mathrm{H} \text {. }\end{array}$ \\
\hline
\end{tabular}

* Species selected from DE

Pollinating efficacy was determined by comparing dynamic behavior of visitors, i.e., visitation rate (Landry, 2013) and resident time with consideration of morpho-structural characteristics of the visited insects. Other aspects like, host specificity, host range and pollination syndrome were also studied.

Rate of visitation $(20 \mathrm{~min})=.\frac{\text { number of particular species (insect) visits }}{\text { Number of flowers studied }}$

Resident time $=$ Time spend by visitor on a single visit to a particular flower

A Jaccard index $\left(\mathrm{C}_{\mathrm{j}}\right)$ was calculated to compare species similarity between the two study sites.

$C_{j}=\frac{a}{a+b+c}$

where:

$\mathrm{a}=$ The number of species common to both sites

$\mathrm{b}=$ The number of species in DE, but not in BWS

$\mathrm{c}=$ The number of species in site BWS, but not in DE

\section{Results}

A total of 53 species of insects were identified from flowers of studied mangrove species (Table 2; Supp. Table 1 and 2). The result excludes very small insects that were insignificant of carrying pollens. Identified insects belong to 7 orders, 24 families and from 44 genera. The representative orders were Coleoptera, Diptera, Hymenoptera, Lepidoptera, Orthoptera, Hemiptera and Odonta (Table 2 and Figure 1). Lepidoptera and Hymenoptera showed highest species diversity then others (22 spp. and 18 spp., respectively). Diptera and Coleoptera had only 5 and 4 species, respectively. Two species were from Hemiptera and one species each recorded from Orthoptera and Odonta. Out of the total, butterflies:19 spp., bees:8 spp., ants:6 spp., flies:5 spp., wasps and beetles:4 spp. each, moths:3 spp., bugs:2 spp. and one species each of crickets and dragonfly (Table 2 and Figure 2). The flowers of different mangrove species attract insects but variation exists between host range visited by a specific insect. Apis dorsata (Honeybee), Micraspis discolor (Ladybird beetle), Crematogastor spp. (Ant) and Cochliomyia macellaria (Flies) had wide host range then others (Figure 3). Maximum 15 insects were recorded from $A$. corniculatum and 12 recorded from E. agallocha (Figure 4). C. crista, a mangrove associate (climber) was found visited by 9 insects but most of them were moths and butterflies. The result showed flowers of four mangals, A. rotondifolia, A. marina, K. candel and E. indica were visited by eight insects each. Only, 
Panda et al. /Journal of Tropical Forestry and Environment Vol. 9, No. 02 (2019), 78-92

3 insect species had been recorded from flowers of $H$. fomes and B. gymnorhiza (Figure 4). Among insects, bees were the most frequent visitors and they visited to 18 mangal species (82\% of studied mangroves) and particularly "Honeybee", i.e., Apis dorsata visited to sixteen mangrove species (i.e., 73\% mangroves) (Figure 3 and Figure 5). Dragonfly and crickets were very rare flower visitors.

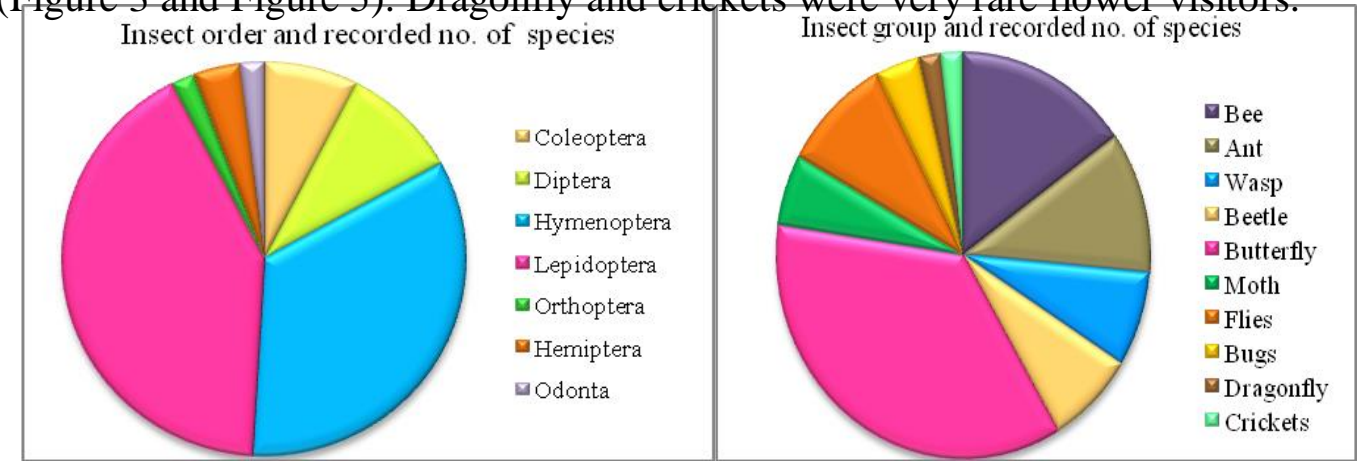

Figure 1. Insect order wise number of insect species. Figure 2. Insect group wise number of species.

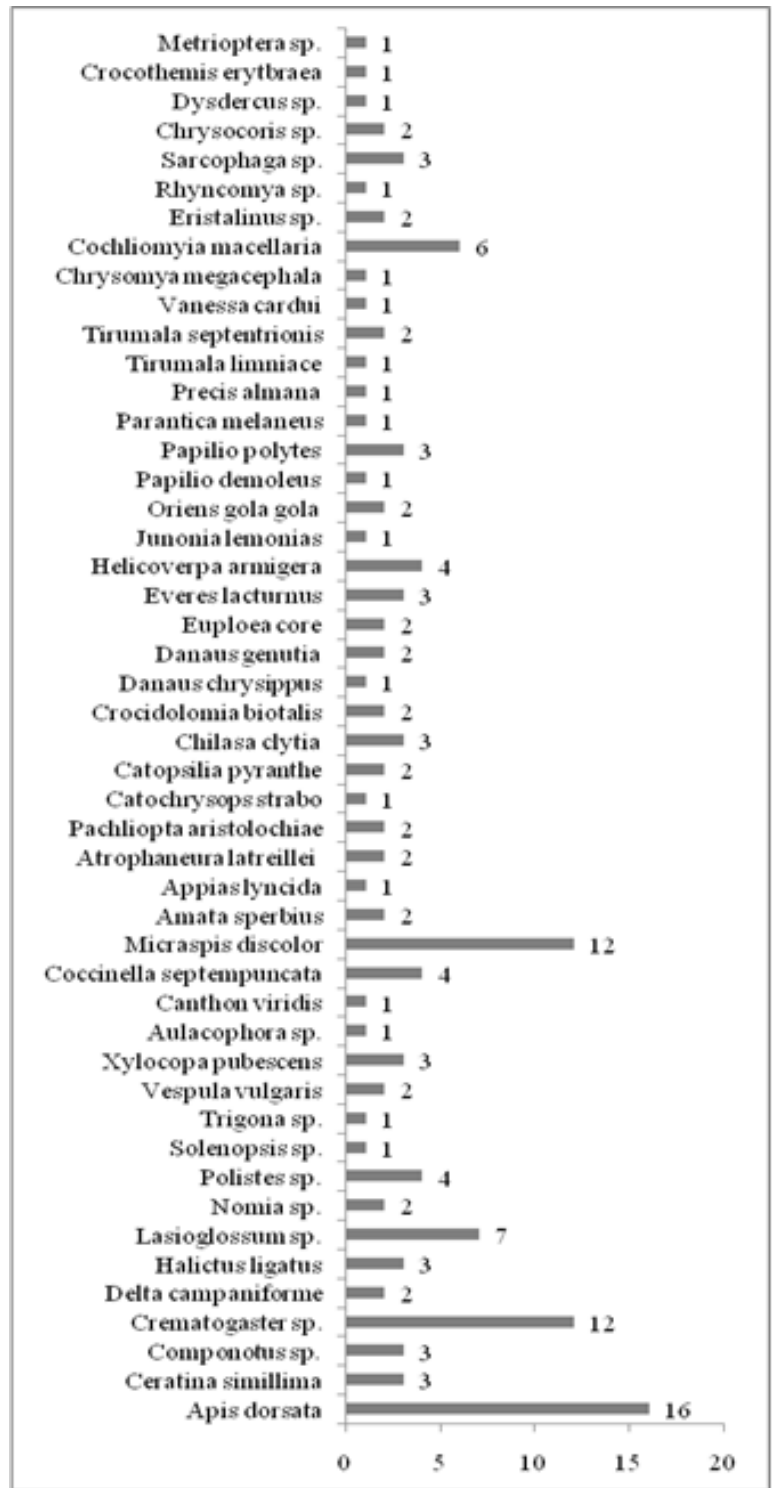


Figure 3. Showing host range of recorded insects (number of mangrove taxa visited by insects).

The comparison of resident time among insect groups showed a large variation. Bees and wasps were found more dynamic and frequent flower visitors. Similarly, study of visitation rate showed high rate for bees, wasps, flies and butterflies, respectively in comparison with other recorded insect groups (Table 3). Moths had more residing time on flowers than others. The increasing trend of resident time is as Bee $<$ Butterfly $<$ Wasp $<$ Flies $<$ Dragonfly $<$ Beetle $<$ Crickets $<$ Bugs $<$ Ants $<$ Moth .

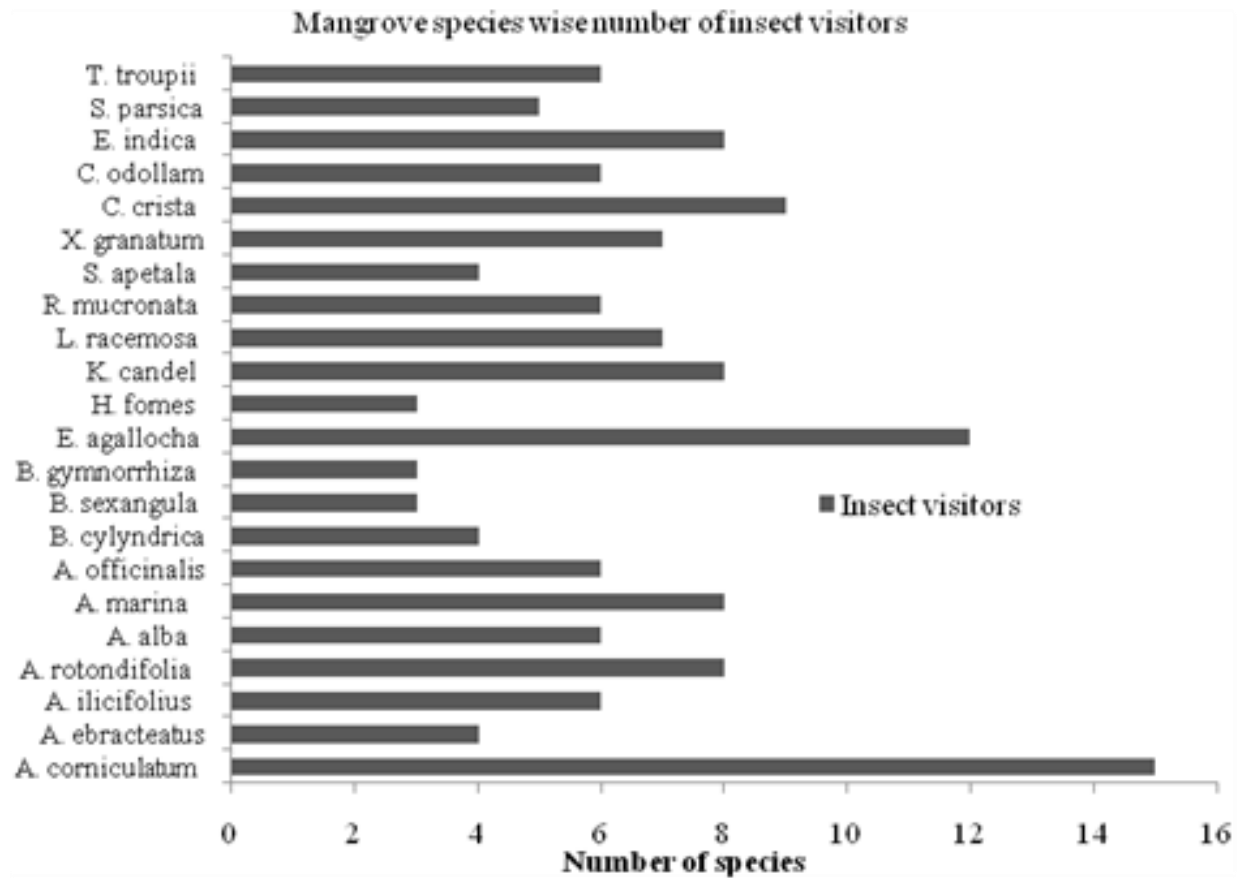

Figure 4. Mangrove species wise recorded number of visited insect species.

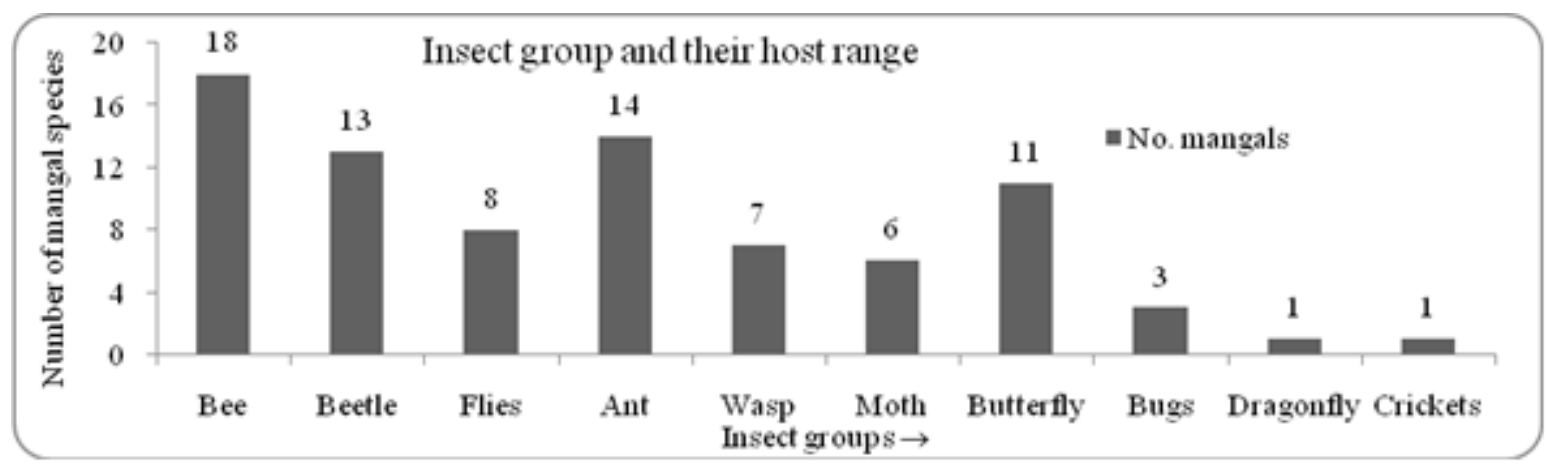

Figure 5: Insect group and their visited number of mangrove species. 
Panda et al. /Journal of Tropical Forestry and Environment Vol. 9, No. 02 (2019), 78-92

Table 2: Recorded insects from mangrove flowers and their classification ( $\mathrm{spp}=\mathrm{species).}$

\begin{tabular}{|c|c|c|c|c|}
\hline SI.No. & Name of insect & Order & Family & Insect class \\
\hline 1 & Apis dorsata & Hymenoptera & Apidae & Bee \\
\hline 2 & Ceratina simillima & Hymenoptera & Apidae & Bee \\
\hline 3 & Componotus spp. 1 & Hymenoptera & Formicidae & Ant \\
\hline 4 & Componotus spp. 2 & Hymenoptera & Formicidae & Ant \\
\hline 5 & Componotus spp. 3 & Hymenoptera & Formicidae & Ant \\
\hline 6 & Crematogaster spp. 1 & Hymenoptera & Formicidae & Ant \\
\hline 7 & Crematogaster spp. 2 & Hymenoptera & Formicidae & Ant \\
\hline 8 & Delta campaniforme & Hymenoptera & Vespidae & Wasp (Yellow potter) \\
\hline 9 & Halictus ligatus & Hymenoptera & Halictidae & Bee \\
\hline 10 & Lasioglossum spp.1 & Hymenoptera & Halictidae & Bee \\
\hline 11 & Lasioglossum spp.2 & Hymenoptera & Halictidae & Bee \\
\hline 12 & Nomia spp. & Hymenoptera & Halictidae & Bee (Sweet bee) \\
\hline 13 & Polistes olivaceus & Hymenoptera & Vespidae & Wasp \\
\hline 14 & Polistes spp. 2 & Hymenoptera & Vespidae & Wasp \\
\hline 15 & Solenopsis spp. & Hymenoptera & Formicidae & Ant \\
\hline 16 & Trigona spp. & Hymenoptera & Apidae & Bee \\
\hline 17 & Vespula vulgaris & Hymenoptera & Vespidae & Wasp \\
\hline 18 & Xylocopa pubescens & Hymenoptera & Apidae & Bee \\
\hline 19 & Aulacophora spp. & Coleoptera & Chrysomelidae & Beetle \\
\hline 20 & Canthon viridis & Coleoptera & Scarabaeidae & Beetle \\
\hline 21 & Coccinella septempuncata & Coleoptera & Coccinellidae & Beetle (Lady bird) \\
\hline 22 & Micraspis discolor & Coleoptera & Coccinellidae & Beetle (Lady bird) \\
\hline 23 & Amata sperbius & Lepidoptera & Arctiinae & Moth \\
\hline 24 & Appias lyncida & Lepidoptera & Pieridae & Butterfly \\
\hline 25 & Atrophaneura latreillei & Lepidoptera & Papilionidae & Butterfly \\
\hline 26 & Pachliopta aristolochiae & Lepidoptera & Papilionidae & Butterfly \\
\hline 27 & Catochrysops strabo & Lepidoptera & Lycaenidae & Butterfly \\
\hline 28 & Catopsilia pyranthe & Lepidoptera & Pieridae & Butterfly \\
\hline 29 & Chilasa clytia & Lepidoptera & Papilionidae & Butterfly \\
\hline 30 & Crocidolomia biotalis & Lepidoptera & Crambidae & Moth \\
\hline 31 & Danaus chrysippus & Lepidoptera & Nymphalidae & Butterfly \\
\hline 32 & Danaus genutia & Lepidoptera & Nymphalidae & Butterfly \\
\hline 33 & Euploea core & Lepidoptera & Nymphalidae & Butterfly \\
\hline 34 & Everes lacturnus & Lepidoptera & Lycaenidae & Butterfly \\
\hline 35 & Helicoverpa armigera & Lepidoptera & Noctuidae & Moth \\
\hline 36 & Junonia lemonias & Lepidoptera & Nymphalidae & Butterfly \\
\hline 37 & Oriens gola gola & Lepidoptera & Hesperiidae & Butterfly \\
\hline 38 & Papilio demoleus & Lepidoptera & Papilionidae & Butterfly \\
\hline 39 & Papilio polytes & Lepidoptera & Papilionidae & Butterfly \\
\hline 40 & Parantica melaneus & Lepidoptera & Nymphalidae & Butterfly \\
\hline 41 & Precis almana & Lepidoptera & Nymphalidae & Butterfly \\
\hline 42 & Tirumala limniace & Lepidoptera & Nymphalidae & Butterfly \\
\hline 43 & Tirumala septentrionis & Lepidoptera & Nymphalidae & Butterfly \\
\hline 44 & Vanessa cardui & Lepidoptera & Nymphalidae & Butterfly \\
\hline 45 & Chrysomya megacephala & Diptera & Calliphoridae & Flies \\
\hline 46 & Cochliomyia macellaria & Diptera & Calliphoridae & Flies \\
\hline 47 & Eristalinus spp. & Diptera & Syrphidae & Flies \\
\hline 48 & Rhyncomya spp. & Diptera & Calliphoridae & Flies \\
\hline 49 & Sarcophaga spp. & Diptera & Sarcophagidae & Flies \\
\hline 50 & Chrysocoris spp. & Hemiptera & Scutelleridae & Bugs \\
\hline 51 & Dysdercus spp. & Hemiptera & Pyrrhocoridae & Bugs \\
\hline 52 & Crocothemis erytbraea & Odonata & Libellulidae & Dragonfly \\
\hline
\end{tabular}


Table 3: Resident time and Visitation rate of each insect class.

\begin{tabular}{lcc}
\hline Flower visitors & $\begin{array}{c}\text { Resident time }(\mathrm{S}) \\
(\text { Mean } \pm \text { SE) }\end{array}$ & $\begin{array}{c}\text { Visitation rate }(\mathrm{m}) \\
(\text { Mean } \pm \text { SE) }\end{array}$ \\
\hline Bee & $14.17 \pm 2.11$ & $35.83 \pm 5.68$ \\
Beetle & $34.67 \pm 3.28$ & $4.17 \pm 1.23$ \\
Flies & $23.08 \pm 3.42$ & $5.33 \pm 1.25$ \\
Wasp & $20.58 \pm 1.96$ & $6.00 \pm 1.47$ \\
Butterflies & $19.92 \pm 2.01$ & $3.60 \pm 0.66$ \\
Ant & $53.75 \pm 4.83$ & $2.67 \pm 0.67$ \\
Moths & $97.00 \pm 12.27$ & $2.40 \pm 0.66$ \\
Bugs & $50.17 \pm 4.04$ & $3.00 \pm 0.82$ \\
Dragonflies & $28.00 \pm 2.56$ & $2.50 \pm 0.41$ \\
Crickets & $45.67 \pm 2.31$ & $1.67 \pm 0.33$ \\
\hline
\end{tabular}

\section{Discussion}

Mangrove flowers are not much eye-catching as like many terrestrial angiosperms. They also lack significant provisions in the form of pollinator rewards. In comparison to other forest or garden plants, few and specific insects do pollination in mangroves. Mangrove community contains species that are both generalists and specialists (Azuma et al., 2002). Our result showed similarity with many previous studies on aspects of pollinator diversity and role in mangrove species pollination (Clarke and Meyerscough, 1991; Pandit and Choudhury, 2001; Azmi et al., 2012; Raju et al., 2012; Raju et al., 2014, Hermansen et al., 2014; Tomlinson, 2016). The report towards visitation of ants, wasp, bugs, flies, bees, cantharid beetles and moths to flowers of $A$. marina by Clarke and Meyerscough (1991) showed similarity to this study. Hermansen et al. (2014) identified 38 species that visited to flowers of $A$. marina but only $A$. mellifera was a significant pollinator. We found $A$. dorsata as a potential pollinator of 16 mangrove species under our study. They had not reported butterfly visits which had been recorded during this particular investigation. In L. racemosa, three groups of flower visitors were found which include bees, wasps and butterflies (Raju et al., 2014). Our study had recorded beetle and ant visitation along with bees and butterflies from flowers of L. racemosa. K. candel is a riverine mangrove, occur along the river banks and influenced by freshwater input. The flowers of this plant produce a chemical (methyl anthranilate) that is known to repel species of birds and insects like bees and butterflies (Azuma et al., 2002). We recorded beetle, wasp and moth along with previously recorded bee and butterflies from flowers of $K$. candel. Pandit and Choudhury (2001) studied a 3 day (both day and night) flower visitors of mangrove species, A. corniculatum and S. ceseolaris at Bhitarkanika. They recorded 17 species of Lepidoptera, 7 species of Hymenoptera, 3 species of Diptera, 5 species of birds and 3 species of mammals from $S$. ceseolaris and 16 species of Lepidoptera, 9 species of Hymenoptera, 2 species of Diptera, 1 species of Coleoptera and 3 species of birds from A. corniculatum. The genus, 'Bruguiera' show specialised pollination through birds. They have large flowers and peculiar tube shape which attracts birds. In $B$. gymnorrhiza, the calyx is red, a colour attractive to birds (Tomlinson, 2016). In this particular study we recorded wasp, bee and ant visitation to B. sexangula; bee and ant from B. gymnorhiza (Table 4). Bees because of their structural adaptations for the collection of pollen are considered to be the most efficient pollinators (Abrol, 2012). Bees as a flower visitor have been observed in many species of the genera like, Acanthus, Aegiceras, Avicennia, Excoecaria, Rhizophora and Xylocarpus (Tomlinson, 2016). Xylocopa varipuncta (carpenter bee) has been identified to carry pollens of exclusive mangroves like, A. alba, $L$. racemosa, $S$. caseolaris, $S$. ovata and $R$. apiculata in the mangrove community of Setiu Wetlands, Terengganu (Azmi et al., 2012). Bumble bee visited flowers show increased seed set than when plant excluded from it (Miller-Struttmann, 2017). Carpenter bees have long tongue which gathers mainly 
pollen, but not nectar. Carpenter bee is one among the most efficient agents for cross pollination in mangrove flowers (Mani, 1995). We found it's strong association with flowers of E. agallocha and A. Corniculatum (Plate 1). This bee is very dynamic and flies actively back and forth to flowers which help in pollen dispersal and deposition. The sweet bees (Lasioglossum spp.) are recorded from mangroves like, A. corniculatum, A. rotondifolia, B. gymnorhiza, K. candel and $R$. mucronata (Supp. Table 1). They were regular visitors in flowers of $A$. corniculatum (Plate 1). Their hind legs help and make them a good candidate for pollen dispersal. Comparison of host range showed bee, ant, beetles, butterfly, flies and wasps were more general flower visitors than moths, bugs, crickets and dragonfly which were rare and occasional visitors (Figure 5).

Previously, no beetle pollinated flowers had been recorded from mangroves, which are considered to be "primitive" pollinators and typically associated with large flowers or inflorescences of much generalised type (Tomlinson, 2016). This particular study had recorded lady bird beetle (Micraspis discolor) visitation from 12 mangroves (54\%) and thought to have a major contribution and bringing pollination in species like A. corniculatum, B. cylindrical, S. apetala, A. ilicifolius, $C$. decandra and $K$. candel (Figure 3, Plate 1). R. mucronata primarily wind pollinated but insect visitation also reported which supports our work.

Table 4: Mangrove species and their flower visitor class identified in the present study.

\begin{tabular}{|c|c|c|c|c|c|}
\hline & True mangroves & Visitor class & & True mangroves & Visitor class \\
\hline 1 & A. corniculatum (L.) & Bee, Flies, Wasp, Beetle, & 13 & K. candel (L) Druce & Bee, Beetle, Wasp, \\
\hline 2 & A. ebracteatus Vahl. & Bee, Beetle, Wasp, & 14 & L. racemosa Willd. & Bee, Beetle, Ant, Butterfly, \\
\hline 3 & A. ilicifolius $\mathrm{L}$. & Bee, Beetle, Butterfly, & 15 & R. mucronata Lamk. & Bee, Beetle, Ant \\
\hline 4 & A. rotondifolia Roxb. & Bee, Wasp, Ant & 16 & S. apetala Buch. - Ham. & Beetle, Moth, Bird \\
\hline 5 & A. alba Blume & Bee, Beetle, Dragonfly, & 17 & $X$. granatum Koenig & Bee, Beetle, Moth, Bugs, \\
\hline 6 & A. marina (Forsk.)Veierh & Bee, Beetle, Moth, Flies, & \multicolumn{3}{|c|}{ Mangrove associates } \\
\hline 7 & A. officinalis $\mathrm{L}$. & Bee, Beetle, Ant, Flies, & 18 & C. crista $\mathrm{L}$. & Butterfly, Crickets, Moth, \\
\hline 8 & B. cylyndrica (L.) Blume & Beetle, Ant, Flies & 19 & C. odollam Gaertn & Ant, Butterfly, Moth, \\
\hline 9 & B. sexangula (Lour.) & Bee, Ant, Wasp, Bird & 20 & E. indica (Willd.) Mull. & Bee, Flies, Ants, Butterfly, \\
\hline 10 & B. gymnorrhiza $(\mathrm{L})$ & Bee, Ant, Bird & 21 & S. parsica $\mathrm{L}$. & Bee, Beetle, Flies, Ant, Bird \\
\hline 11 & E. agallocha $\mathrm{L}$. & Bee, Wasp, Flies, Bugs, & 22 & T. troupii $\mathrm{H}$. & Bee, Butterfly, Bird \\
\hline 12 & H. fomes Buch-Ham. & Bee, Ant, Spider & & & \\
\hline
\end{tabular}

Ant and honey bee visitation to flowers of $H$. fomes showed their role in pollination of this south Asian endemic species. High resident time indicates it to be a forging species. An insect having high visitation rate and low resident time is a good pollinator (Landry, 2013). Our study showed, bees, butterflies, and wasps are efficient mangrove pollinators with low resident time and high visitation rate (Table 3). The species of former group with highest visitation rate, low resident time and with structural adaptation placed them a potential candidate in bringing mangrove pollination. Bugs, moths and ants were forging species and contribute little to the mangrove pollination as lack structural adaptation to carry pollens from flowers.

We reviewed literature of eighteen mangrove species that showed all species were more or less associated with biotic pollinators like insects more commonly from family Hymenoptera, Diaptera, Coleoptera and Lepidoptera (Marshall, 1983; Clarke and Meyerscough, 1991; Raju et al., 1994; Sun et al., 1998; Naskar and Mandal, 1999; Pandit and Choudhury, 2001; Raju et al., 2006; Ghosh et al., 2008; Nagarajan et al., 2010; Ghosh and Chakraborti, 2012; Raju et al., 2012; Pandey and Pandey, 2013; Hermansen et al., 2014; Raju and Raju, 2014; Raju et al., 2014; Tomlinson, 2016) (Table 5). The latter two groups spend enough time for nectar foraging. Mangrove flowers are not much attractive but still able fascinate few unique insects that bring successful pollination. 
The work of Faegri and Pijl (1979) and Abrol (2012) on pollination syndrome (characters which attracts or favors for pollination) also supported our findings (Table 6). The yellow/brown coloured flower of Avicennia sp. and B. sexangula; Blue colour in A. ilicifolius are commonly visited by bees. White flowered species of $A$. corniculatum and $A$. rotondifolia with ample nectar were found to be frequently visited by bees, i.e., Honeybee and Losioglossum spp. (Supp. Table 1; Plate 1). Thus, attracting pollinators is a prerequisite for reproductive success in angiosperms (Moyroud and Glover, 2017). Past work showed the genus, Sonneratia have night blooming flowers which attract bats for foraging and pollination (Table 5). Beetle and moth visits to flowers of Sonneratia spp. had been recorded from this study (Table 4). Butterfly visitation to T. troupii; flies visitation to E. agallocha and E. indica; beetle visitation to $A$. corniculatum, $A$. rotondifolia, $K$. candel and $R$. mucronata etc., bird pollination in $B$. sexangula and B. gymnorhiza; moth visitation of mangrove associates like, $C$. odollam and $C$. crista; ant visits to $A$. corniculatum and $A$. rotondifolia, X. granatum and $H$. fomes were supported by previous studies on pollination syndrome (Faegri and Pijl, 1979; Abrol, 2012).

Table 5: Result of literature review showing studies on flower visitors and pollinators of different mangrove species.

\begin{tabular}{|c|c|c|c|c|c|}
\hline \multirow[b]{2}{*}{ Mangrove } & \multicolumn{4}{|c|}{ Insect } & \multirow[b]{2}{*}{ Bats } \\
\hline & Wind & $(\mathrm{H} / \mathrm{D} / \mathrm{C})$ & $\begin{array}{l}\text { Butterfly } \\
\text { (L) }\end{array}$ & Bird & \\
\hline A. corniculatum (L.) Blanco & - & $3,5,6,12 *^{\circ}$ & 6,12 & 6,12 & - \\
\hline A. rotondifolia Roxb. & - & 5 & - & - & - \\
\hline A. illicifolius L. & - & $3 *$ & - & 3 & - \\
\hline A. alba Blume & - & $11 *$ & 11 & - & - \\
\hline A. marina (Forsk.)Veierh & - & $2 *, 10 *, 11,13$ & 2 & - & - \\
\hline A. officinalis $\mathrm{L}$. & - & $3,11 *^{\circ}$ & 11 & - & - \\
\hline R. mucronata Lamk. & $3,5,8,16$ & $8^{*}, 10 *$ & - & - & - \\
\hline B. cylindrical (L.) Blume & - & 16 & 3,5 & - & - \\
\hline B. gymnorhiza (L.) Lamk. & - & $9 *$ & - & $3,5,16$ & - \\
\hline B. sexangula (Lour.) Poir & - & $9 *$ & - & $3,5,16$ & - \\
\hline C. crista $\mathrm{L}$. & - & $5^{\circ}, 14 *^{\circ}$ & 14 & - & - \\
\hline C. decandra (Griff.) Ding Hou & - & $8,7,10 *, 16$ & - & - & - \\
\hline E. agallocha $\mathrm{L}$. & - & $5 *$ & - & - & - \\
\hline K. candel (L) Druce & - & $3,4 *^{\circ}, 5,16$ & 4,5 & - & - \\
\hline L. racemosa Willd. & - & $3,15 *, 16$ & 15 & - & - \\
\hline Sonneratia sp. & - & & - & - & 1,16 \\
\hline$X$. granatum Koenig & - & $5^{*}$ & - & - & - \\
\hline H. fomes Buch.-Ham. & - & $5^{*}$ & - & - & - \\
\hline
\end{tabular}

Note: 1: Marshall, 1983; 2: Clarke and Meyerscough, 1991; 3: Raju et al., 1994; 4: Sun et al., 1998; 5: Naskar and Mandal, 1999; 6: Pandit and Choudhury, 2001; 7: Raju et al., 2006; 8: Ghosh et al., 2008; 9: Nagarajan et al., 2010; 10=Ghosh and Chakraborti, 2012; 11: Raju et al., 2012; 12: Pandey and Pandey, 2013; 13: Hermansen et al., 2014; 14: Raju and Raju, 2014; 15: Raju et al., 2014; 16: Tomlinson, 2016

[H: Hymenoptera, D: Diaptera, C: Coleoptera, L: Lepidoptera and $*=$ Honeybee, ${ }^{\circ}=$ Bumble bee]

Among the four bee species i.e., honey bee, carpenter bee, sweet bee and bumble bee, we observed that honey bees were more common and visited inflorescence in group. A single inflorescence of Salvadora parsica was noted to host approximately about 10-15 honey bees at a particular time. Similar results were recorded from mangroves like, A. corniculatum, A. marina and B. sexangula. Carpenter bees were the second most sociable after honey bees and recorded in groups of approximately 3-4 from the flowers of $A$. corniculatum and E. agallocha. Bumble bee and sweet bee were rare and single individuals had been recorded from the visited flowers. During this particular work we noted anti-herbivory role of Micraspis discolor (Ladybird beetle) which prevents leaf herbivory and damage in many mangrove species. Leaf area loss by herbivores is a common phenomenon in mangroves like genera Avicennia, Kandelia, Cerops and Rhizophora. Presence of Micraspis discolor on mangrove leaves protect leaves from herbivory damages along with play a critical role in pollination (Plate 1). Honey bee not only brings 
Panda et al. /Journal of Tropical Forestry and Environment Vol. 9, No. 02 (2019), 78-92

successful pollination, it also supports the earnings of local livelihood through high quality honey production. About 200 tons of honey and 50 tons of beeswax are harvested annually from reserve forest of Sundarbans (Gani, 2001). This is 50 percentage of total honey production of Bangladesh. In Bhitarkanika, honey is collected by the local people largely to sell in the market as resource for their livelihood (Hussain and Badola 2010). 
Table 6: Pollination syndromes: Traits of flowers pollinated by different pollinators, (Adapted after, Faegri and Pijl, 1979; Abrol, 2012).

\begin{tabular}{|c|c|c|c|c|c|c|c|}
\hline Pollinator class & Floral morphology & Colour & Scent & Nectar tube & Primary attractants & Toughness & Floral opening \\
\hline $\begin{array}{l}\text { Insects } \\
\text { (Entomophily) }\end{array}$ & Differs with type of pollinators & Yes & Yes & Yes & & Not enough & Day and night \\
\hline $\begin{array}{l}\text { Bees } \\
\text { (Melitophily) }\end{array}$ & $\begin{array}{l}\text { Zygomorphic with great depth } \\
\text { effect, mechanically strong } \\
\text { adequate landing facility }\end{array}$ & $\begin{array}{l}\text { Blue, yellow, } \\
\text { purple (except } \\
\text { red) }\end{array}$ & Sweet smell & $\begin{array}{l}\text { Nose size or } \\
\text { Long body } \\
\text { width }\end{array}$ & $\begin{array}{l}\text { Nectar hidden deep; } \\
\text { sucrose rich; } \\
\text { abundant pollen }\end{array}$ & $\begin{array}{l}\text { Not enough, have a } \\
\text { landing platform or } \\
\text { lip }\end{array}$ & Day and night \\
\hline $\begin{array}{l}\text { Flies } \\
\text { (Myophily) }\end{array}$ & $\begin{array}{l}\text { Actinomorphic, regular, } \\
\text { simple, funnel-like }\end{array}$ & $\begin{array}{l}\text { Light or dull, } \\
\text { whitish }\end{array}$ & Imperceptible & Open cups & Nectar & Not tough & Day and night \\
\hline $\begin{array}{l}\text { Butterflies } \\
\text { (Psychophily) }\end{array}$ & $\begin{array}{l}\text { Actinomorphic, flowers in } \\
\text { group, erect radial, good } \\
\text { landing facilities }\end{array}$ & $\begin{array}{l}\text { Dull brown, } \\
\text { white, blue and } \\
\text { purple }\end{array}$ & Weak & Long narrow & $\begin{array}{l}\text { Nectar in ample } \\
\text { quantities, hidden at } \\
\text { base of pollen tubes }\end{array}$ & $\begin{array}{l}\text { Not tough, no landing } \\
\text { platform }\end{array}$ & Day and night \\
\hline $\begin{array}{l}\text { Moths } \\
\text { (Phalaenophily) }\end{array}$ & $\begin{array}{l}\text { Actinomorphic or } \\
\text { Zygomorphic, horizontal }\end{array}$ & $\begin{array}{l}\text { Pale, purple, } \\
\text { white }\end{array}$ & $\begin{array}{l}\text { Strong sweet, } \\
\text { nocturnal }\end{array}$ & Long narrow & $\begin{array}{l}\text { Nectar in large but } \\
\text { hidden in tubes }\end{array}$ & $\begin{array}{l}\text { Not tough, no landing } \\
\text { platform }\end{array}$ & Night \\
\hline $\begin{array}{l}\text { Ants } \\
\text { (Myrmecophily) }\end{array}$ & Small, sessile, close to ground & $\begin{array}{l}\text { *White, purple, } \\
\text { blue }\end{array}$ & *Faint & $*$ Hidden deep & Nectar and Pollen & & *Day and night \\
\hline $\begin{array}{l}\text { Beetles } \\
\text { (Cantharophily) }\end{array}$ & $\begin{array}{l}\text { Actinomorphic, large shallow, } \\
\text { often bowl shaped blossoms }\end{array}$ & $\begin{array}{l}\text { Dull white, } \\
\text { purple or brown }\end{array}$ & Strong fruity & No & $\begin{array}{l}\text { Mostly pollen, } \\
\text { Sometimes nectar }\end{array}$ & Not enough & Day and night \\
\hline $\begin{array}{l}\text { Wasp } \\
\text { (Sphecophily) }\end{array}$ & & Dull brown & & & Nectar & & Day and night \\
\hline $\begin{array}{l}\text { Birds } \\
\text { (Ornithophily) }\end{array}$ & $\begin{array}{l}\text { Large container like, tubular or } \\
\text { funnel like strong supports for } \\
\text { perch. }\end{array}$ & $\begin{array}{l}\text { Red, yellow or } \\
\text { orange }\end{array}$ & $\begin{array}{l}\text { No (birds } \\
\text { can't smell) }\end{array}$ & Long wider & $\begin{array}{l}\text { Nectar, insects } \\
\text { sitting flower, rarely } \\
\text { pollen }\end{array}$ & $\begin{array}{l}\text { Tough, leathery, } \\
\text { plenty of nectar }\end{array}$ & Day and night \\
\hline $\begin{array}{l}\text { Wind } \\
\text { (Anemophily) }\end{array}$ & $\begin{array}{l}\text { Regular, small, Unisexual } \\
\text { (either monoecious or } \\
\text { dioecious species), highly } \\
\text { reduced perianth, anthers and } \\
\text { stigmas exerted }\end{array}$ & $\begin{array}{l}\text { Yellow or } \\
\text { brown, may be } \\
\text { absent or } \\
\text { reduced }\end{array}$ & No & No & ------- & $\begin{array}{l}\text { Not tough, big } \\
\text { anthers, plenty of } \\
\text { pollen. Stigmas } \\
\text { feathery to catch the } \\
\text { pollen }\end{array}$ & Day and night \\
\hline
\end{tabular}

* From present study 
Panda et al. /Journal of Tropical Forestry and Environment Vol. 9, No. 02 (2019), 78-92

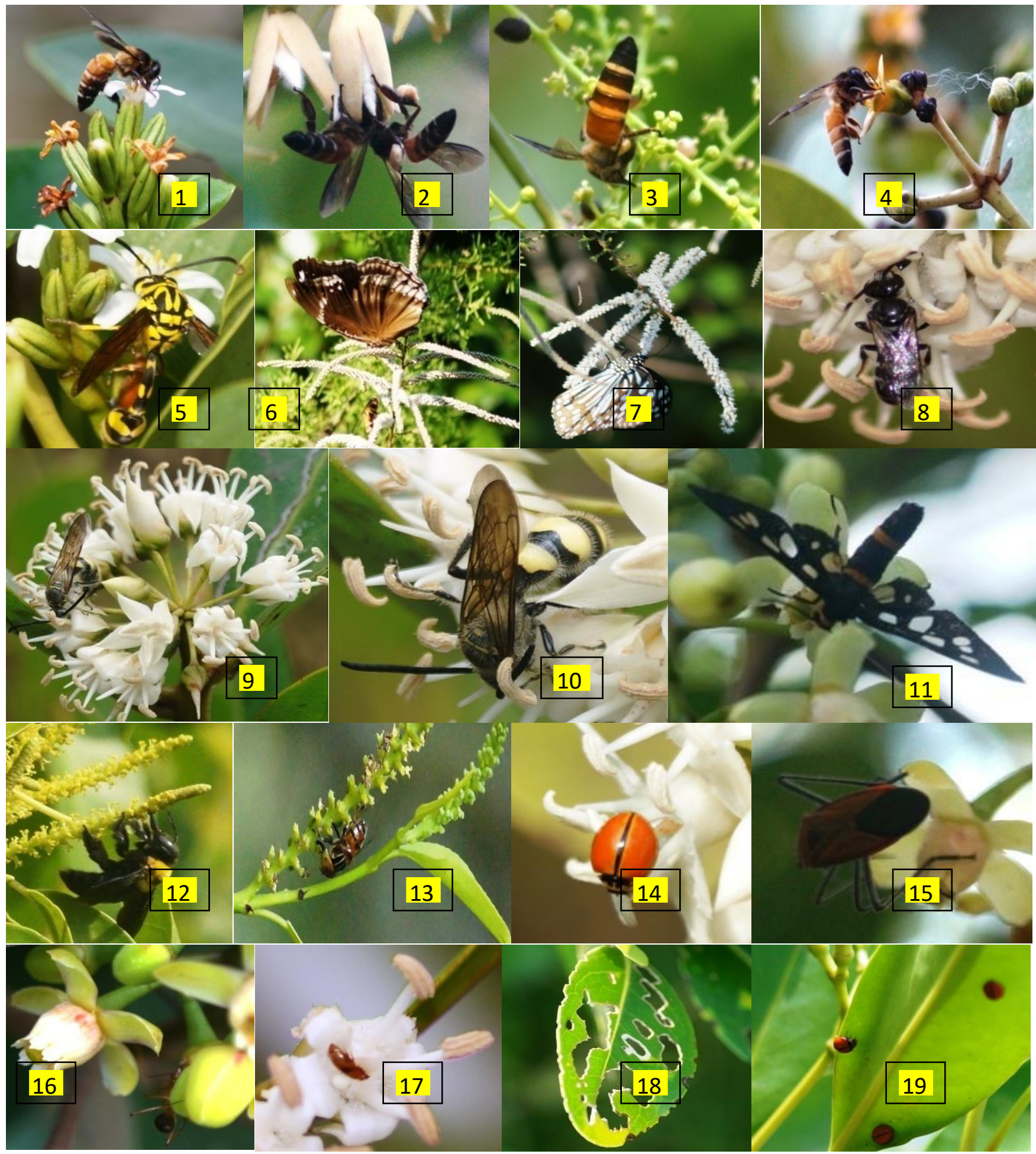

Plate 1: Flower visitors and presumed pollinators in different mangrove species of BWS and DE.

[Note: 1-4: A. dorsata (Giant honey bee) on flowers of A. rotondifolia, R. mucronata, S. parcica and A. officinalis, respectively; 5: Vespula sp. on flower of A. rotondifolia; 6-7: Euploea core and Tirumala limniace on flowers of $T$. troupii, respectively; 8: Lasioglossum sp. 1 on flower of $A$. corniculatum; 9-10: Lasioglossum sp. 2 on flower of $A$. corniculatum; 11: Amata sperbius feeding on flowers of X. granatum; 12: Xylocopa pubescens visiting flowers $E$. agallocha; 13: Nomia sp. on E. indica; 14: Micraspis discolor sitting on flower of A. corniculatum; 15 \& 16: Dysdercus sp. (bug) \& Ant visitation on flowers of X. granatum, respectivly; 17: A bug (Aulacophora sp.) sitting 
on A. corniculatum; 18: Herbivory of mangrove leaves; 19: Undamaged leaves in presence of Micraspis discolor on K. Candel]

\section{Conclusion}

Mangroves are exclusively seed propagated plants. Excluding Rhizophora spp. which bears predominantly wind pollinated mangroves, all other species more or less depend on biotic agents/pollinators for effective pollen transfer. Habitat degradation, conversion to aquaculture land, use of pesticides in agriculture, introduction of exotic plant species are strongly affecting the existence and action of natural pollinators. 'Bhitarkanika' being the second large single mangrove patch in India, presently experiencing loss of species diversity for which it was previously known throughout the globe. Impact of climate change on pollinator availability and specialist pollination in mangroves can further studied towards effective management of fragile ecosystem like mangrove.

Giving more emphasis on bee keeping can help to increase the reproductive success and seed output in many mangroves. Not only the honey bee but others like Carpenter bee (Xylocopa spp.), Sweet bee (Lasioglosum spp.) may need to be given priority for increase of their population. Conservation of associate mangrove species will give additional advantage to maintain true mangrove diversity as they provide alternative forage during non flowering period of true mangrove species. Making policies and law to prevent use of harmful chemicals in peripheral agriculture land will help to prevent further loss of these natural pollinators. The anti-herbivory role of the predatory ladybird beetle and effect of climate change on pollinator availability in this fragile coastal ecosystem may be further investigated and can be used towards long term management.

\section{Acknowledgment}

We are thankful to PCCF, Wildlife (Odisha), DFO- Rajnagar and staffs of mangrove forest division of BWS for their support and valuable contribution during our field survey.

\section{References}

Abrol, D.P., 2012. Pollination biology: biodiversity conservation and agricultural production. Springer Science, 792.

Alongi, D.M., 2009. The energetics of mangrove forests. Springer Science, 216.

Azmi, W.A., Ghazi, R. and Mahamed, N.Z., 2012. Importance of Carpenter Bee, Xylocopa varipuncta (Hymenoptera: Apidae) as Pollination Agent for Mangrove Community of Setiu Wetlands, Terengganu, Malaysia. Sains Malaysiana, 41:1057-1062.

Azuma, H., Toyota, M., Asakawa, Y., Takaso, T. and Tobe, H., 2002. Floral scent chemistry of mangrove plants. Journal of Plant Research, 115:47-53.

Capinera, J.L., 2010. Insects and wildlife: arthropods and their relationships with wild vertebrate animals. John Wiley and Sons Ltd., 487.

Chinery, M (2007). Insects of Britain and Western Europe. Domino Books Ltd., 320.

Clarke, P.J. and Meyerscough, P.J., 1991. Floral biology and reproductive phenology of Avicennia marina in south eastern Australia. Australian Journal of Botany, 39:283-293.

Faegri, K. and Pijl, L., 1979. The principles of pollination ecology. Pergamon Press Ltd., 244.

Gani, M.O., 2001. The giant honey bee (Apis dorsata) and honey hunting in Sundarbans reserved forests of Bangladesh. In: Proceedings of $37^{\text {th }}$ International Apiculture Congress, held in $28^{\text {th }}$ Oct. $-1^{\text {st }}$ Nov., 2001, Durban, South Africa, 1-10.

Ghosh, A. and Chakraborti, P., 2012. Evaluation of some mangrove species on the nature of their reproduction along coastal belt of the Indian Sunderbans. Journal of Threatened Taxa, 4:24272435.

Ghosh, A., Gupta, S., Maity, S. and Das, S., 2008. Study of Floral Morphology of Some Indian Mangroves in Relation to Pollination. Research Journal of Botany, 3:9-16. 
Hermansen, T.D., Britton, D.R., Ayre, D.J. and Minchinton T.E., 2014. Identifying the Real Pollinators? Exotic Honeybees Are the Dominant Flower Visitors and Only Effective Pollinators of Avicennia marina in Australian Temperate Mangroves. Estuaries and Coasts, 37:621-635.

Hogarth P.J., 2015. The biology of mangroves and Seagrasses. Oxford University Press, New York, 289.

Hussain, S.A. and Badola, R., 2010. Valuing mangrove benefits: contribution of mangrove forests to local livelihoods in Bhitarkanika Conservation Area, East Coast of India. Wetlands Ecology and Management, 18:321-331.

Jagtap, T.G., Chavan, V.S. and Untawale, A.G., 1993. Mangrove Ecosystems of India: A Need for Protection. Ambio, 4:252-254.

Kathiresan, K. and Bingham, B.L., 2001. Biology of Mangroves and Mangrove Ecosystems. Advance In Marine Biology, 40:81-251.

Kearns, C.A. and Inouye, D.W., 1997. Pollinators, Flowering Plants, and Conservation Biology: Much remains to be learned about pollinators and plants. Bioscience, 47:297-307.

Landry C.L., 2013. Pollinator-mediated competition between two co-flowering Neotropical mangrove species, Avicennia germinans (Avicenniaceae) and Laguncularia racemosa (Combretaceae). Annals of Botany, 111:207-214.

Mani M.S., 1995. Insects. National Book Trust, India, 162.

Marshall A.G., 1983. Bats, Flowers and Fruit: Evolutionary Relationships in the Old World. Biological Journal of the Linnean Society, 20, 125-135.

Miller-Struttmann, N.E., Heise, D., Schul, J., Geib, J.C. and Galen, C., 2017. Flight of the bumble bee: Buzzes predict pollination services. PLOS ONE, 12:1-14.

Mitra, B., Biswas, O., Roy, S. and Chakraborti, U., 2013. Pollinators of mangroves in the perspective of Indian Sundarbans. ENVIS Newsletter, 21:6-11.

Moyroud, E. and Glover, B.J., 2017. The physics of pollinator attraction. New Phytologist. 216: 350-354.

Nagarajan, M., Krishnamoorthy Padmini, S. and Daniel, A., 2010. Nectar robbery in bird pollinated mangroves! Current Science, 98:603-604.

Naskar, K. and Mandal, R., 1999. Ecology and Biodiversity of Indian Mangroves. Daya Publishing House, Delhi, Vol. I and II, 754.

Noske, R.A., 1993. Bruguiera hainesii: Another Bird-Pollinated Mangrove? Biotropica, 25:481-483.

Pandey, R. and Pandey, C.N., 2013. Spatial and Temporal variations in floral visitors of a mangrove species-Aegiceras corniculatum (L.) Blanco-In the Marine National Park, Gujarat, India. International Journal of Botany and Research, 3:35-42.

Pandit, S. and Choudhury, B., 2001. Factors affecting pollinator visitation and reproductive success in Sonneratia caseolaris and Aegiceras corniculatum in a mangrove forest in India. Journal of Tropical Ecology. 17:431-447.

Pratap, U., 2011. The Pollination Role of Honeybees. In: Honeybees of Asia, ed. H.R. Hepburn and S.E. Radloff, Berlin, Springer Science, 227-255.

Raju, A.J.S., 1990. Studies on Pollination Ecology in India: A review. Proceedings of Indian National Science Academy, B56, 4:375-388.

Raju, A.J.S., Jonathan, K.H. and Lakshmi, A.V., 2006. Pollination biology of Ceriops decandra (Griff.) Ding Hou (Rhizophoraceae), an important true viviparous mangrove tree species. Current Science. 91:1235-1238.

Raju, A.J.S., Kumar, R. and Rajesh B., 2014. Pollination ecology of Lumnitzera racemosa Willd. (Combretaceae), a non-viviparous mangrove tree. Taprobanica, 6:100-109.

Raju, A.J.S., Rao, P.V.S., Kumar, R. and Mohan, S.R., 2012. Pollination biology of the crypto-viviparous Avicennia species (Avicenniaceae). Journal of Threatened Taxa. 4:3377-3389. 
Raju, A.J.S., Reddi, C.S. and Sujatha, B., 1994. Pollination in mangrove plants. Journal of Natcon, 6:8996.

Raju, P.S. and Raju, A.J.S., 2014. Pollination ecology of the Gray Nicker Caesalpinia crista (Caesalpiniaceae) a mangrove associate at Coringa Mangrove Forest, Andhra Pradesh, India. Journal of Threatened Taxa, 6:6345-6354.

Resh, V.H. and Carde, R.T. (ed.), 2009. Encyclopedia of Insects. Elsevier, Inc., 1132.

Robertson, A.I., 1991. Plant-animal interactions and the structure and function of mangrove forest ecosystems. Australian Journal of Ecology. 16:433-443.

Singh, A.P., 2011. Butterflies of India. Om Books International, 183.

Smetacek, P., 2017. A naturalist's guide to the Butterflies of India. John Beaufoy Publishing Limited. 176.

Sun M., Wong K.C. and Lee J.S.Y., 1998. Reproductive biology and population genetic structure of Kandelia candel (Rhizophoraceae), A viviparous mangrove species. American Journal of Botany. 85:1631-1637.

Tomlinson, P.B., 2016. The Botany of Mangroves. Cambridge University Press, Cambridge, UK, 418. 